\title{
Comparison of Anchorage Systems for Externally Bonded FRP Laminates
}

\author{
Wael.R.Ibrahim ${ }^{1}$, Waleed.A.Ali ${ }^{2}$ \\ ${ }^{1,2}$ Civil Department,Faculty of Engineering at Mataria' Helwan University \\ ${ }^{1,2}$ Cairo, Egypt \\ ${ }^{1}$ wael.ibrahim@rwth-aachen.de \\ ${ }^{2}$ Waleed_abdallah@m-eng.helwan.edu.eg
}

\begin{abstract}
This paper reports the results of an experimental program to investigate the bonding behaviour of two different types of anchorage systems for externally bonded FRP laminates for strengthening one way RC slab, mechanicaland fiber anchorage system. The overall experimental program consisted of seven flexure tests on $\mathrm{RC}$ slab specimens strengthened with a mechanical anchorage system and another seven flexure tests on RC slab specimens strengthened with a fiber anchorage system. The influence of different types of anchorage systems, numbers of anchors and anchor spacing are studied in this paper to evaluate the behaviour of strengthened one-way slabs. The performance of each anchorage system is presented, discussed, and compared in terms of deflection, debonding mode, and failure mode. General from the experimental results, it is found the anchorage system significantly reduces the slab deflections and increases the slab strength and slip capacity, in comparison with unanchored control slabs. The findings indicate that the mechanical technique could represent a better alternative to the fiber anchorage technique because it allows debonding to be more delayed, and hence FRP tensile strength to be better exploited.
\end{abstract}

Keywords: Anchors, Flexural, RC slabs, FRP, strengthening

\section{INTRODUCTION}

Many old concrete structures need strengthening due to the new codesrequirements and increasing of allowable loads. Externally Bonding FRP sheets to the tension face of a RC flexural member with fibers oriented along the length of the member will provide an increase in flexural strength. The application of Fiber Reinforced Polymer (FRP) as Externally Bonded Reinforcement (EBR) for strengthening of existing Reinforced Concrete (RC) structures is a widely used technique and its effectiveness when compared to conventional methods as in [2]. Lawrence et al.[3] studied 75 reinforced concrete beams strengthened using mechanicallyfastened fiber reinforced polymer (MF-FRP). They concluded that, the advanced composites have a high tensile strength, in shear and torsional retrofit applications, but there is a problem due to the ineffective bond between the composite and the concrete. Bonacci et al. [13] studied numerous tests. It was seen that FRP de-bonded on average at a strain level of about $50 \%$ of the material's tensile capacity.Ibrahimet al. [11, 12] studied reinforced concrete slabs with anchors, they concluded that, the mechanical anchors are provided anchorage along the bonded length that led to a profound improvement of the bond behaviour, and particularly for the full anchorage FRP bonded strengthened slabs. This technique is applied more, and becomes an attractive solution for strengthening the RC structures; however, achieving the full tensile capacity of the externally bonded FRP is often very difficult especially for elements with an inadequate length which leading to premature bonding failure. Anchorage system must be applied to avoid the premature failure and to transfer the load carried by the FRP laminates directly into the structure. The anchors can be used to enable effective FRP strengthening solutions to be developed for a wide range of RC structural elements. A few researches focused on the anchoring systems, but the results were mixed and inconclusive. This research aimed to experimentally investigate the contribution of the applied, two different anchoring systems, steel and fiber, to upgrade the capacity of RC slabs strengthened in flexural with CFRP strips. The experimental program,including fourteen specimens' slabs, twelve are strengthened slabs in addition to the two control specimensare conducted to study the effect of the anchorage system on the slab flexural behaviour. The tested slabs are simply supported on two sides with fixed dimensions $2000 \times 400 \times 120 \mathrm{~mm}$. Two specimens are strengthened and tested without any anchorage system. The studied parameters in this research are anchor types, (steel-fiber), anchor numbers, (onetwo-three)and the anchor spacing (100-150-200mm), to evaluate the behaviour of strengthened one way slabs.Slabs are simply supported on two sides and measure 2000 x 400 x $120 \mathrm{~mm}$. Two specimensare strengthened and tested without an anchorage system. The studied parameters in this research are anchor types, (steel-fiber), anchor numbers, (one-two-three) and the anchor spacing (100-150-200mm), to evaluate the behaviour of strengthened one way slabs. 


\section{A. Materials}

\section{Test Program}

The 28-day compressive strength of concrete is $30 \mathrm{MPa}$. The steel reinforcement is Grade 360 with nominal yield and ultimate strength of 360 and $520 \mathrm{MPa}$, respectively. The CFRP strip is Sika S1012. Sika CarboDur S1012 has an elasticity modulus of 165,000MPa, a rupture tensile strength of $3100 \mathrm{MPa}$ and an ultimate elongation of $1.5 \%$. Sika ${ }^{\circledR} 30$ epoxy is used for bonding. As provided by the manufacture, its tensile strength at 7 days is $24 \mathrm{MPa}$. Steel and fiber anchors are shown in Fig. 1, 2 respectively. The steel wedge bolts are single piece with diameter $12 \mathrm{~mm}$, heavy duty anchors that are driven into pre-drilled holes. Driving of the wedge bolt can be performed with a common rotary drill.

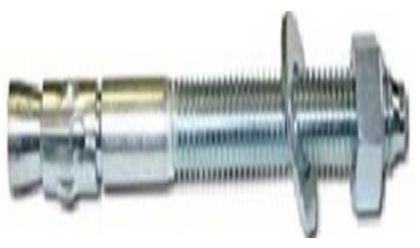

Fig.1.Steel anchor.

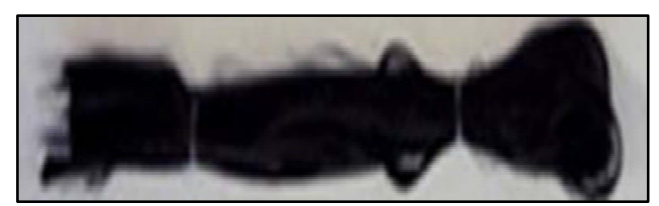

Fig.2. Fiber anchor.

\section{B. Test Specimen}

The test specimen is $2000 \mathrm{~mm}$ long, $400 \mathrm{~mm}$ wide and $120 \mathrm{~mm}$ deep. Each slab is singly reinforced at tension side by $4 \Phi 12$ with a clear cover $20 \mathrm{~mm}$ as shown in Fig.3. For the strengthened slabs, one CFRP strip with $1750 \mathrm{~mm}$ length, $50 \mathrm{~mm}$ width and $1.2 \mathrm{~mm}$ thickness is bonded to the tension face of the slab. Sika ${ }^{\circledR} 30$ epoxy is used for bonding. The Properties of CFRP composites are given in Table I.

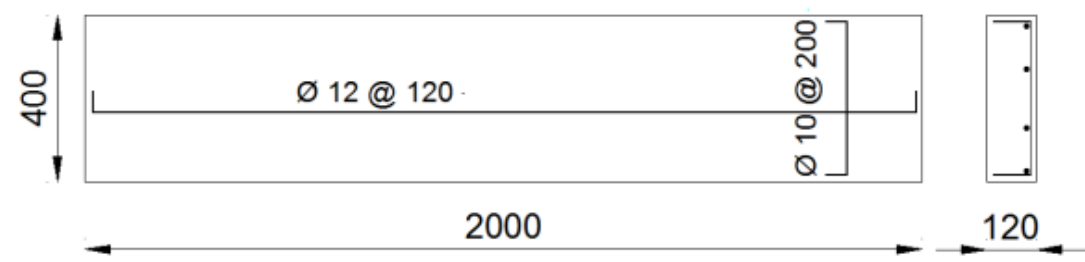

Fig.3. Specimen dimensions and reinforcement details.

TABLE I. Properties of CFRP Composites

\begin{tabular}{|c|c|c|c|c|}
\hline Composite type & Thickness mm & Strength MPa & $\begin{array}{c}\text { Modulus of } \\
\text { Elasticity MPa }\end{array}$ & Rupture strain $\mu \varepsilon$ \\
\hline $\begin{array}{c}\text { Unidirectional } \\
\text { fiber }\end{array}$ & 1.20 & 3100 & 165,000 & 15,000 \\
\hline
\end{tabular}

\section{Test Matrix}

The test matrix is given in Table 2. A total of fourteen slabs are used in this study. Two slabs(S-01and S-02) are used as control specimens while the other twelve slabs are strengthened with CFRP strip. Two slabs (S-03 and S-04) are without strengthened anchors. Slabs (S-05, S-06, S-07, S-08 and S-09) had fiber anchors and slabs (S-10, S-11, S-12, S-13and S-14) had steel anchors. Slabs (S-05 and S-10) had two anchors, one anchor at each end, as shown in Figs 6 and 7 respectively, while slabs (S-06, S-07, S-08, S-011, S-12, and S-13) have fouranchors, two anchors at each end with different anchor spacing 100, 150, and $200 \mathrm{~mm}$ as indicated in Table II.Slabs (S-09 and S-14) had six anchors, three at each end with anchor spacing $200 \mathrm{~mm}$. All specimens' details are shown in Fig.4. 
TABLE III. Test Matrix

\begin{tabular}{|c|l|c|c|c|}
\hline Specimen No & \multicolumn{1}{|c|}{$\begin{array}{c}\text { Specimen } \\
\text { Symbol }\end{array}$} & Anchor Type & Anchor No & $\begin{array}{c}\text { Anchor } \\
\text { Spacing (mm) }\end{array}$ \\
\hline S-01 & SC-01 & -- & -- & -- \\
\hline S-02 & SC-02 & -- & -- & -- \\
\hline S-03 & SC-A1 & -- & -- & -- \\
\hline S-04 & SC-A2 & -- & -- & -- \\
\hline S-05 & SC-AF-2-000 & Fiber & 2 & -- \\
\hline S-06 & SC-AF-4-100 & Fiber & 4 & 100 \\
\hline S-07 & SC-AF-4-150 & Fiber & 4 & 150 \\
\hline S-08 & SC-AF-4-200 & Fiber & 4 & 200 \\
\hline S-09 & SC-AF-6-200 & Fiber & 6 & 200 \\
\hline S-10 & SC-AS-2-000 & Steel & 2 & -- \\
\hline S-11 & SC-AS-4-100 & Steel & 4 & 100 \\
\hline S-12 & SC-AS-4-150 & Steel & 4 & 150 \\
\hline S-13 & SC-AS-4-200 & Steel & 4 & 200 \\
\hline S-14 & SC-AS-6-200 & Steel & 6 & 200 \\
\hline
\end{tabular}

Note: S-control slab without strengthening, SC-AF-n-000 (Slab with CFRP strips - Type of Anchor (Fiber) No of Anchor - Anchor Spacing. SC-AS-n-000 (Slab with CFRP strips - Type of Anchor (Steel) - No of Anchor - Anchor Spacing.

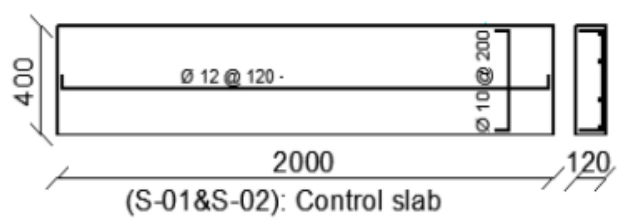

(S-01\&S-02): Control slab

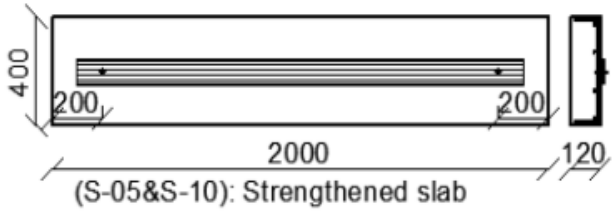

with 2 anchors

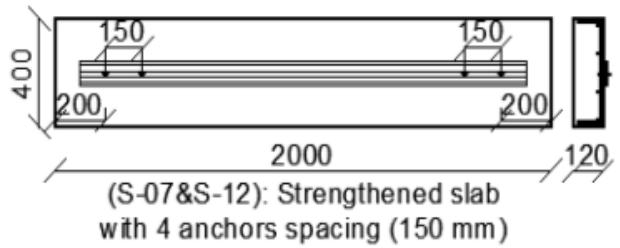

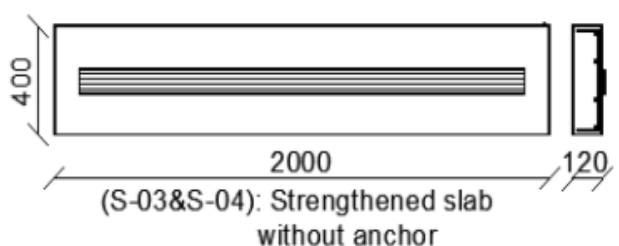
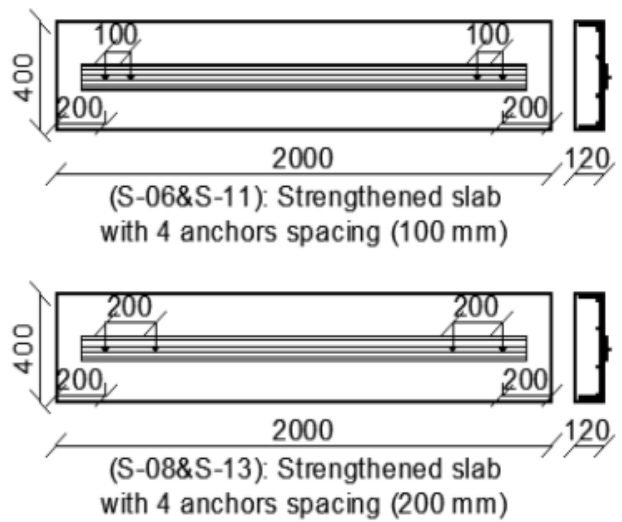

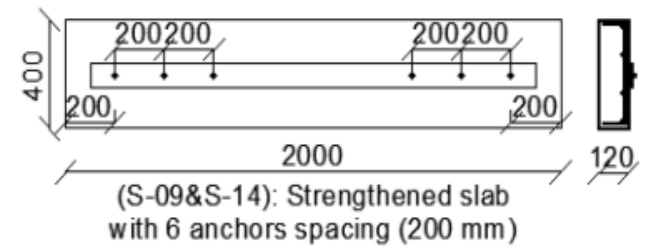

Fig.4. Specimens details 


\section{Test Set-up and Instrumentation}

A very rigid steel frame consisting of horizontal and vertical I-sections was used as a base to support slab specimens. The tests were carried out in the reinforced concrete laboratory of the Faculty of Engineering, ElMataria, Helwan University. The slab specimens were mounted in a horizontal position inside the steel frame to serve as a simple line support along the two edges of the slabs. All slabs are tested with an effective span of $1800 \mathrm{~mm}$ and a shear span of $600 \mathrm{~mm}$. load is applied monotonically at the mid-span of the slab using a hydraulic actuator having a capacity of $200 \mathrm{kN}$. A spreader beam is used to transfer the load to the slab through two loading points placed at the ends of the middle third of the slab span as shown in Fig 5.One (LVDT) is placed under the mid-point of the slab to measure the deflection while a load cell is used to record the load. One strain gauge is bonded to the surface of the CFRP strip, at the mid-span. Similarly one strain gauge is bonded to the steel reinforcement bar, at the mid-span.The development of cracks and deflection were observed during loading and recorded after each increment till failure.

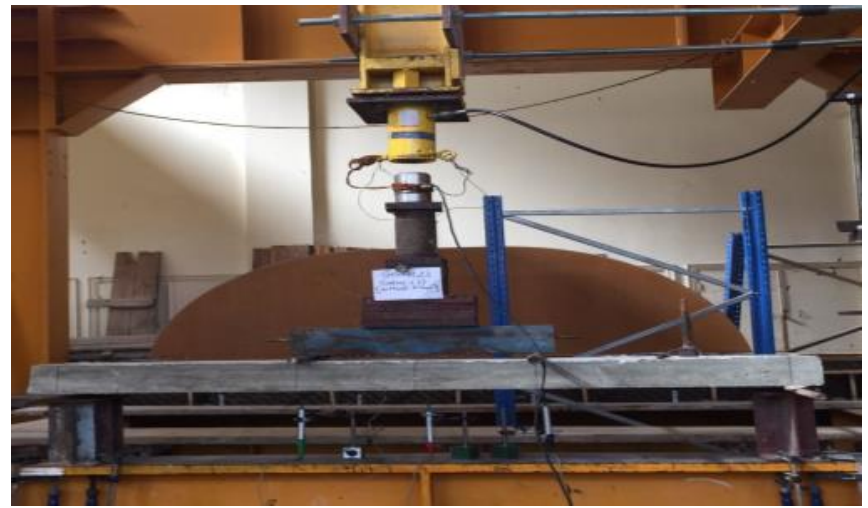

Fig.5. Testset up.

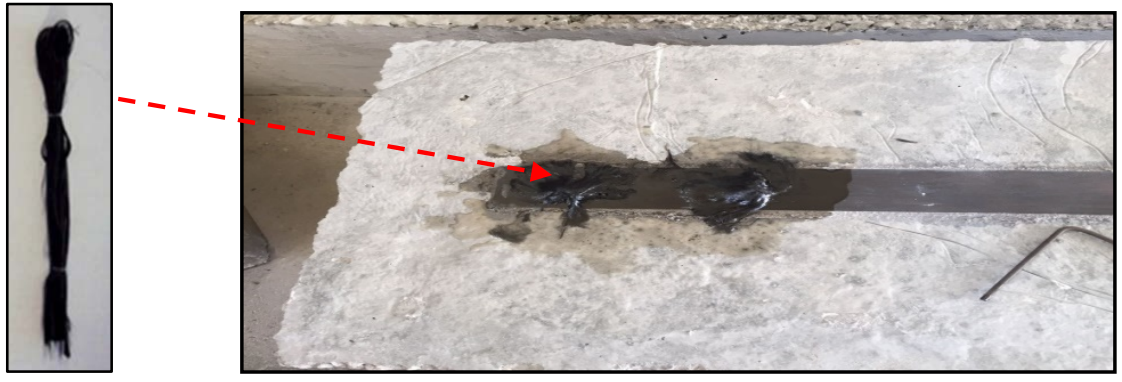

Fig.6. Slab (S-05).

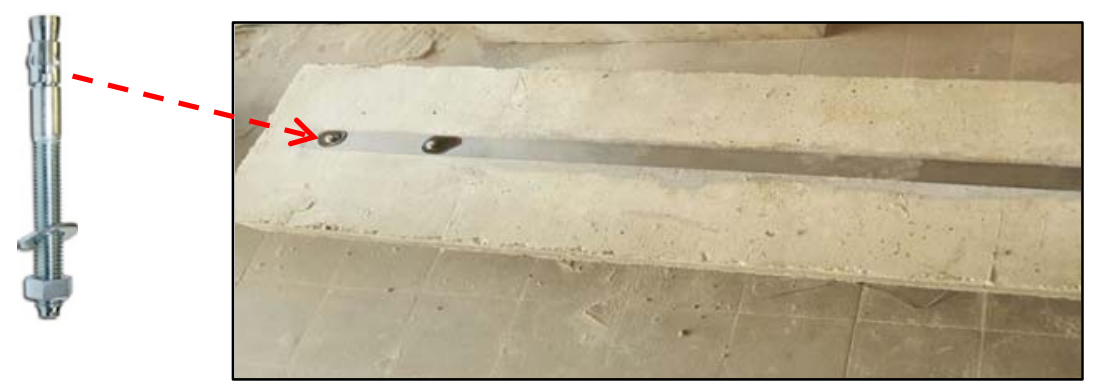

Fig.7. Slab (S-10). 


\section{TEST RESULTS AND DISCUSSION.}

Failure mode, load deflectionand failure loads of the tested specimens were obtained from the experimental study and presented comparatively. The obtained results were analyzed and discussed the effect of used two different anchoring systems, steel and fiber on the behaviour of RC slabs strengthened in flexural with CFRP strips as following:

\section{A. Failure Mode}

The control slab (S-01 and S-02) failed by yielding of steel reinforcement followed by crushing of concrete. Slab (S-03 and S-04),which strengthened by CFRP strip without anchorage, delamination of CFRP had happened without warning after yielding of steel reinforcement. The slabs, which strengthened by CFRP strip with fiber anchors, were failed by bearing failure of CFRP from one side as shown in Fig.8.All the remaining slabs, which strengthened by CFRP strip with minimum two steel anchors, were failed by crushing of concrete, which is preceded by yielding of steel reinforcement, thus the presence of anchorage preventsthe debonding of the CFRP strip and hence the slab developed its full flexural capacity.

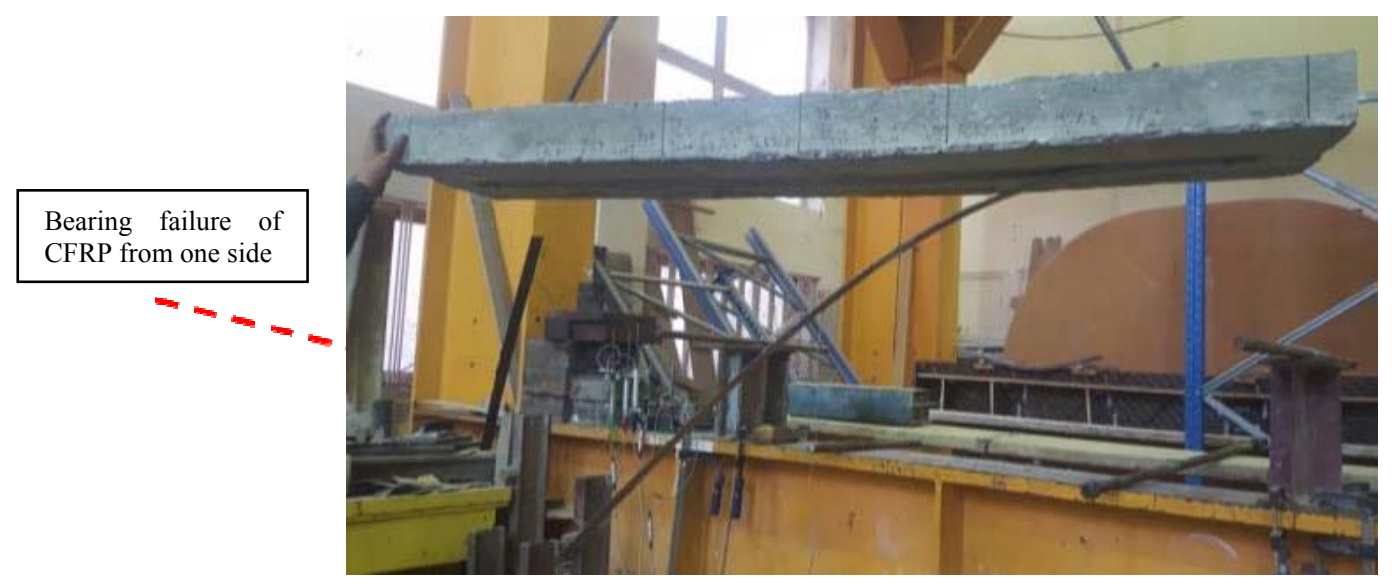

Fig.8. Bearing failure of specimen (S-10)

\section{B. Load-Deflection Relationship}

The loads versus mid-span deflection relationships for all slabs are shown in Table III. The average ultimate load of slabs (S-03 and S-04), which is strengthened by CFRP strip without anchorage, is about $24 \%$ higher than the average of the control slabs load (S-01 and S-02). The slabsstrengthened by CFRP strip with fiber anchors were failed by debonding of the CFRP strip. The average mid-span deflection at ultimate load of the slabs strengthened by CFRP strip with fiber anchors is $12 \%$ higher than the average ultimate loadof the control slab as shown in Fig. 9. Theaverage ultimate load of the slabs strengthened by CFRP strip with fiber anchors is about $38 \%$ higher than that of the average ultimate load of control slabs and $10 \%$ higher than that of the slabs (S-03 and S-04) strengthened by CFRP strip without any anchorage. The average ultimate load of remaining slabs, which is strengthened with CFRP strip andsteel anchorage, is about $75 \%$ and $40 \%$ higher than that of the average ultimate load of control slabs and slabs (S-03 and S-04) respectively. The mid-span deflection at ultimate load of remaining slabs, which is strengthened with CFRP strip and steel anchorage, is about $10 \%$ higher than the average ultimate load of control slabs as shown in Fig. 10. 
TABLE IIIII. Test Results

\begin{tabular}{|c|c|c|c|}
\hline Specimen No & $\mathbf{P}_{\mathbf{u}}(\mathbf{k N})$ & $\boldsymbol{\Delta}_{\mathbf{u}}(\mathbf{m m})$ & Mode of failure \\
\hline S-01 & 34 & 36 & Concrete crushing \\
\hline S-02 & 46 & 23 & Concrete crushing \\
\hline S-03 & 43 & 28 & FRP delamination \\
\hline S-04 & 56 & 26 & FRP delamination \\
\hline S-05 & 52 & 33 & FRP delamination \\
\hline S-06 & 56 & 32 & FRP delamination \\
\hline S-07 & 54 & 32 & FRP delamination \\
\hline S-08 & 55 & 34 & FRP delamination \\
\hline S-09 & 58 & 35 & FRP delamination \\
\hline S-10 & 60 & 30 & FRP delamination \\
\hline S-11 & 70 & 32 & Concrete crushing \\
\hline S-12 & 72 & 32 & Concrete crushing \\
\hline S-13 & 73 & 34 & Concrete crushing \\
\hline S-14 & 75 & 35 & Concrete crushing \\
\hline
\end{tabular}

$\mathrm{P}_{\mathrm{u}}$ and $\Delta_{\mathrm{u}}$ refer to ultimate loads and mid-span deflections, respectively.

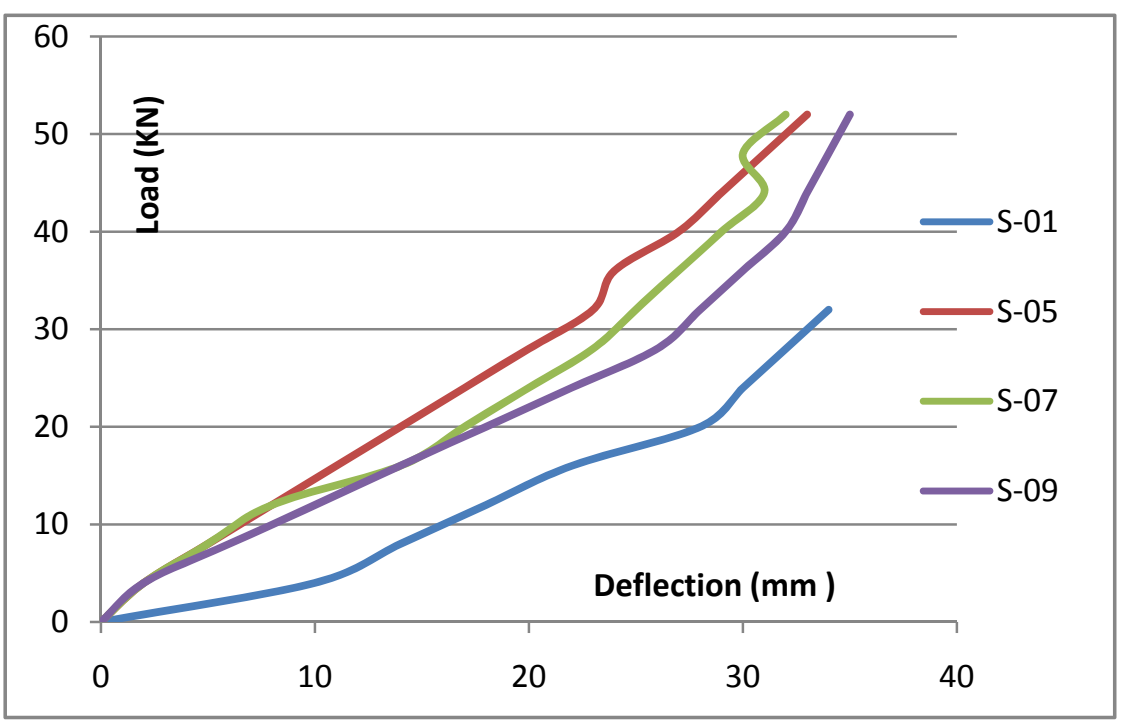

Fig.9. Load-deflection curves for S-01, S-05, S-07 and S-09 Slabs.

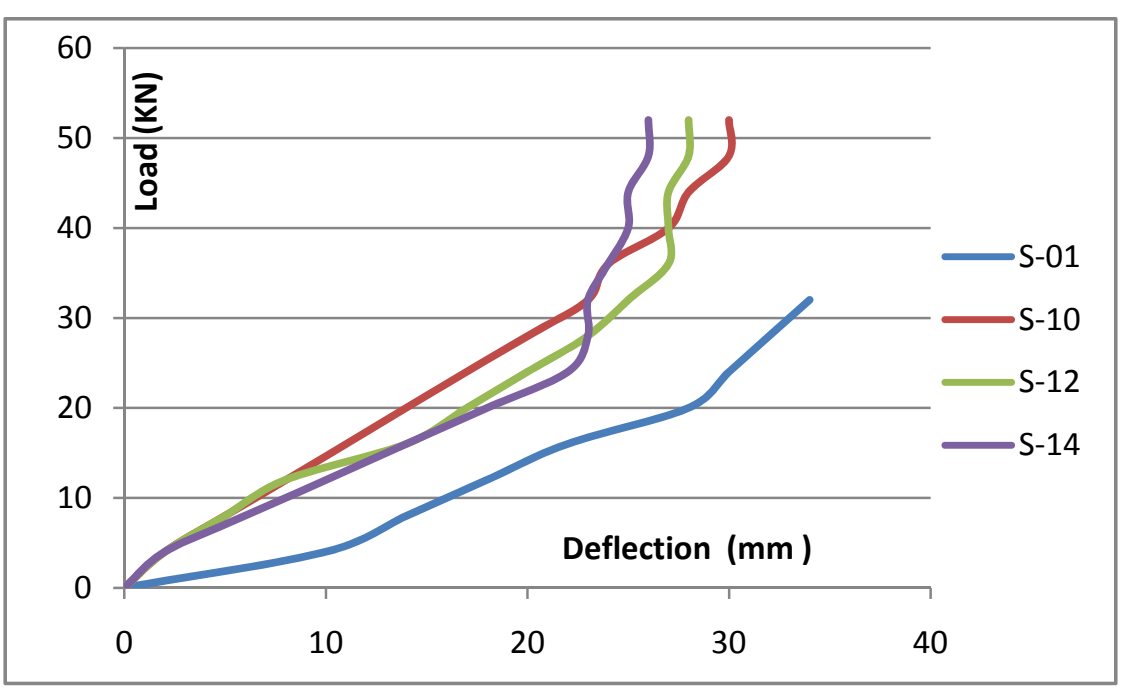

Fig.10. Load-deflection curves for S-01, S-10, S-12 and S-14 Slabs. 


\section{Effect of Fiber Anchorage Type, Numberand Spacing}

The tested slab with two, four with spacing $100 \mathrm{~mm}$ and six fiber anchors is increased by $30 \%, 40 \%$ and $45 \%$ in strength respectively over the average capacity of the control slabs as shown in Fig.11. The debonding load for the previous slabs is increased by $5 \%, 13 \%$ and $17 \%$ respectively compared to the strengthened slab without anchors as shown in Fig. 12. The strength of the tested slab with two, four with spacing $100 \mathrm{~mm}$ and six steel anchors is increased by $50 \%, 75 \%$ and $88 \%$ respectively average capacity of the control slabs as shown in Fig.11. The debonding load for the previous slabs with steel anchors is increased by $21 \%, 41 \%$ and $51 \%$ respectively compared to the strengthened slab (S-03and S-04) as shown in Fig. 12. Although the ductility is reduced in the slabs with FRP reinforcement, the debonding ductility ratio of the slabs with steel anchors is increased over the slabs with fiber anchors. The steel anchors are effective in delaying debonding of the FRP strip by slowing the propagation of debonding cracking. The anchors are provided anchorage along the bonded length that led to a profound improvement of the bond behaviour, particularly for the full anchorage FRP bonded strengthened slabs

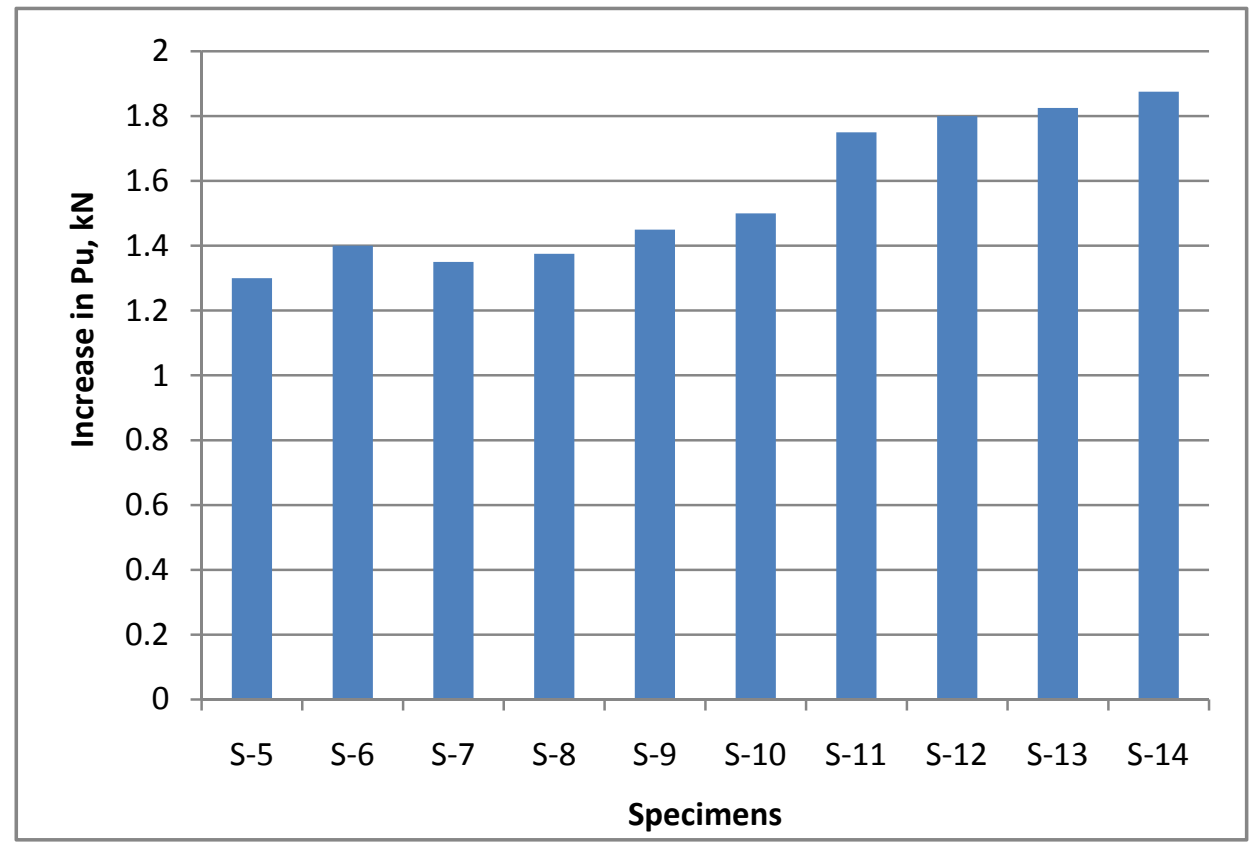

Fig.11. Load increases for specimens with anchorage, kN reference S-01 and S-02.

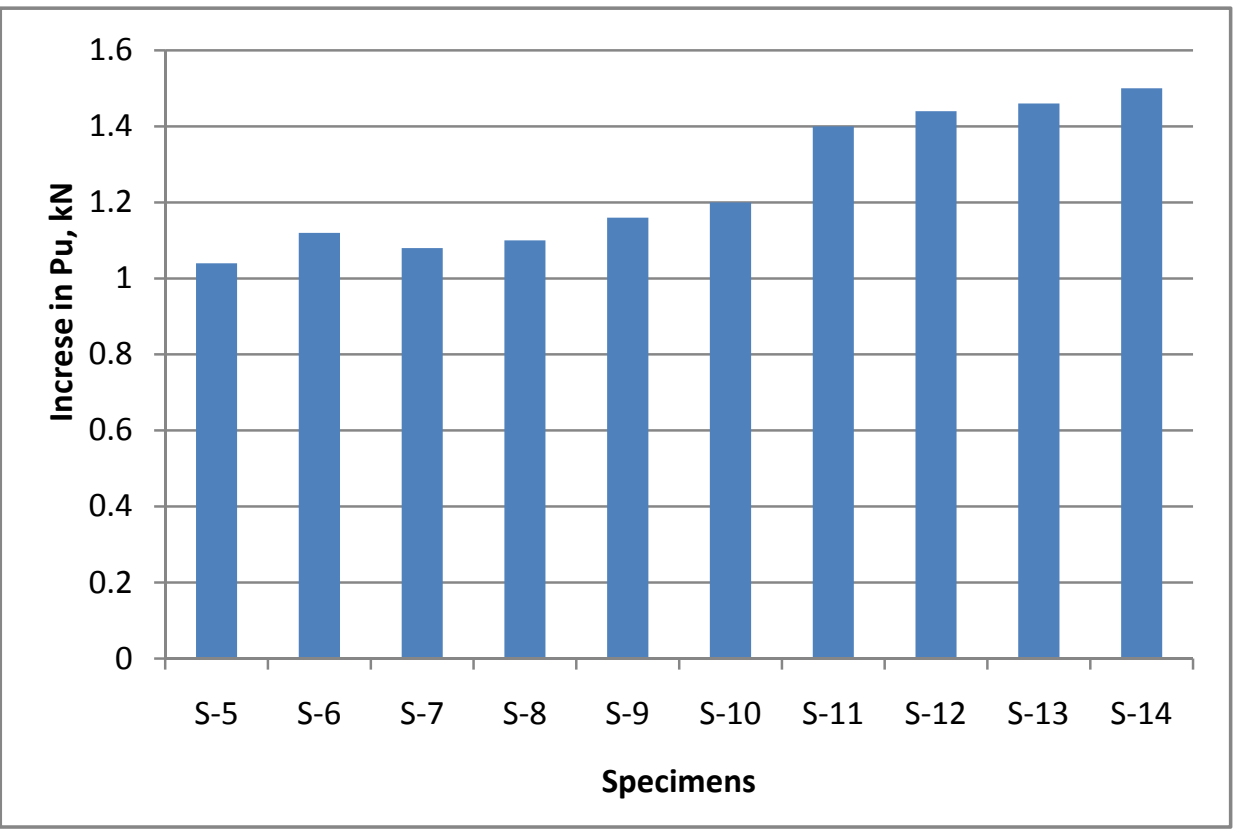

Fig.12. Load increases for specimens with anchorage, kN reference S-03 and S-04. 


\section{CONCLUSIONS}

Based on research results the following conclusions can be drawn.

1. The strengthening slab without anchorage increased the average ultimate loads by about $24 \%$ relative to those of the control slabs.

2. The fiber anchors applied to FRP-strengthened RC slabs are found to increase the average ultimate loads of the slabs by up to $38 \%$, in comparison with control slabs.

3. The average increase in flexural capacity of strengthened slabs with fiber anchors is $10 \%$ relative to strengthening slab without anchorage.

4. The steel anchors applied to FRP-strengthened RC slabs are found to increase the average ultimate loads of the slabs by about $75 \%$ in comparison with the control slabs.

5. The steel anchors are effective in delaying debonding of the FRP strip by slowing the propagation of debonding cracking.

6. The steel anchors are provided anchorage along the bonded length that led to a profound improvement of the bond behavior, particularly for the full anchorage FRP bonded strengthened slabs.

7. The steel anchors spacing 100,150 and 200 are found to have no major influence on the ultimate capacity of the FRP-strengthened RC slabs.

\section{REFERENCES}

[1] ACI (2008) Guide for the Design and Construction of Externally Bonded FRP Systems for Strengthening Concrete Structures, ACI 440.2R-02, (ACI) Committee 440, Michigan, USA.

[2] Al-Mahaidi, R. and Kalfat, R."Investigation into CFRP laminate anchorage systems utilizing bi-directional fabric wrap,"Composite Structures, Vol. 93, No. 4, pp. 1265-1274,2011

[3] Bank, L.C. and Arora, D."Analysis of RC beams strengthened with mechanically fastened FRP (MF-FRP) strips," Composite Structures, Vol. 79, No. 2, pp. 180-191,2007

[4] Burr, A.C. "Recent developments in the use of FRP anchors and masonry all strengtheningtechniques," The Structural Engineer, Vol. 82, No. 18 , pp. 20-21,2004

[5] Ceroni, F., Pecce, M., Matthys, S. and Taerwe, L. "Debonding strength and anchorage devices for reinforced concrete elements strengthened with FRP sheets," Composites Part B, Vol 29, No. 3, pp. 429-441,2008

[6] Chen, J.F. and Teng, J.G. "Anchorage strength models for FRP and steel plates bonded to concrete," Journal of Structural Engineering, Vol. 127, No.7, pp. 784-791,2001

[7] Eshwar, N., Nanni, A. and Ibell, T.J. "Performance of two anchor systems of externallybonded fiber-reinforced polymer laminates," ACI Materials Journal, Vol. 105, No. 1, pp. 72-80,2008

[8] Gose, S.C. and Nanni, A. "Anchorage System for Externally Bonded FRP Laminates using Near Surface Mounted Rods," Report, Centre for Infrastructure Engineering Studies, University of Missouri-Rolla, USA.,2000

[9] Grelle, S.V. and Sneed, L.H. (2011) "An evaluation of anchorage systems for fiber-reinforced polymer (FRP) laminates bonded to reinforced concrete elements,” Proceedings (CD Rom),Structures Congress, American Society of Engineers (ASCE), Las Vegas, USA, 14-16 April 2011.

[10] Kalfat, R., Al-Mahaidi, R. and Smith, S.T. "Anchorage devices used to improve the performance of concrete structures retrofitted with FRP composites," Journal of Composites for Construction, ASCE, doi: 10.1061/ (ASCE)CC.1943-5614.0000276, 2011

[11] Ibrahim, W., and Abdallah, W. "Use of Anchors in flexural Strengthening of RC Slabs with FRP,"APFIS2017 - 6th Asia-Pacific Conference on FRP in Structures. Singapore, 19-21 July 2017.

[12] Ibrahim, W. "Performance of RC Slabs Strengthened with Mechanically Fastened Composites,"SMAR 2017 - Fourth Conference on Smart Monitoring Assessment and Rehabilitation of Civil Structures.Zurich, 15-19September 2017.

[13] Bonacci JF, Maalej M. "Behavioral trends of RC beams strengthened with externally bonded FRP," J Compos Construction ,5(2):10213,2001

[14] Orton SL, Jirsa JO, Bayrak O. "Design considerations of carbon fiber anchors," J Compos Construction 2008; 12(6):608-16.

[15] Vrettos, E. Kefala, T.C. Triantafillou. "Innovative flexural strengthening of RC columns using carbon fiber anchors," ACI Structure J, 110, January 2013

[16] C.W. Niemitz, R. James, S.F. Brena "Experimental behavior of carbon fiber reinforced polymer (CFRP) sheets attached to concrete surfaces using CFRP anchors,"ASCE J Comp Construction, pp. 185-194, February 2010

[17] L. Koutas, A. Pitytzogia, T.C. Triantafillou, S.N. Bousias. "Strengthening of in filled reinforced concrete frames with TRM: study on the development and testing of textile-based anchors,"ASCE J CompConstruction, p. A4013015, 10.1061/ (ASCE)CC.19435614.0000390,March 2014,

[18] L. Koutas, T.C. Triantafillou "Use of anchors in shear strengthening of reinforced concrete T-beams with FRP," ASCE J CompConstruction, pp. 101-107, January 2013

[19] Kim Y, Quinn KT, Satrom CN, Ghannoum WM, Jirsa JO. "Shear strengthening RC T-beams using CFRP laminates and anchors," 10th International symposium on FRP reinforcement for concrete structures. Vol. 275. Detroit: American Concrete Institute; 2011b. p. $1-17$.

[20] S.J. Kim, S.T. Smith“Pullout strength models for FRP anchors in un cracked concrete,"ASCE J Comp Construction, pp. 406-414,April 2010

[21] D.A. Bournas, T.C. Triantafillou "Biaxial bending of RC columns strengthened with externally applied reinforcement combined with confinement," ACI Structure J, 110 , pp. 193-204,February 2013

[22] F. Ceroni, M. Pecce "Evaluation of bond strength in concrete elements externally reinforced with CFRP sheets and anchoring devices,"ASCE J CompConstruction, pp. 521-530,May 2010

[23] Dionysios A. Bournasa, AlbertoPavesebWalidTizania."Tensile capacity of FRP anchors in connecting FRP and TRM sheets to concrete," Engineering StructuresVol.82, pp 72-81, January 2015 